\title{
ELECTROLYTIC CHROMIUM, II
}

\author{
BY H. R. CARVETH AND B. E. CURRY
}

(a) Unusual cathodic deposits. (b) Prevnous work on electrolysis of chromuc acid. (c) Chemeal reactions of chromic acid. (d) Electrochemical relations. (e) Prelimmary electrolyses. ( $f$ ) Experiments with pure acd. (g) Effect of probable impurities.

(h) Comparison of efficiencies. (i) Effect of products of reaction.

(j) Conclusions.

(a) Unusual Cathodic Deposits. - In the first paper on "Electrolytic Chromium" it was remarked that a great diversity of opinion existed as to the possibility of depositing chromium from solutions of chromic acid or chromates. The selection of such a problem for investigation would by many chemists be regarded as an absolute waste of time; but a brief review of the cases where unexpected precipitations at the cathode had been observed confirmed us in the belief that the subject deserved study. The results which are presented in this paper will show that the work of a chemist which for half a century has been considered absolutely false can now, in part at least, be repeated and that a number of hopelessly contradictory statements made by different observers may be reconciled.

In dealing with the cases where the anion or a part of it is deposited at the cathode, two distinct classes of phenomena are met; in the first, the element deposited is a conductor, in the second it is a non-conductor of electricity. In the case of the latter, there is very little doubt that the deposition is not a primary electrolytic effect but that it is due to chemical replacement or reaction. As illustrations may be cited the cathodic deposition of iodine, sulphur and selenium from aqueous solutions of their "ic" acids.

The fused or aqueous alkaline salts of the following elements have served as electrolytes from which have been obtained the conducting metals-lead, tin, zinc, tellurium, arsenic, silicon,

\footnotetext{
${ }^{1}$ Carveth and Mott: Jour. Phys. Chem., 9, 23I (rgo5).
} 
molybdenum, tungsten, uranium, ruthenium and osmium. In these cases the metal is supposed to exist in the solution mainly as part of the anion; nevertheless, to explain conductivity and other results, the assumption has to be made that metallic cations are also present in the solution. The electrodeposition of the metal from such solutions is effected only when a definite electromotive force has been reached. Two explanations of this fact are given: The first is that the deposition from the solution is not necessarily electrolytic but is more probably chemical, being caused by the reaction between the hydrogen or alkali metal and the electrolyte; the second regards the deposition as primarily electrolytic; since the relative number of cations of the element may be very small, the efficiency may be very low.

Does chromium in the chromates exist as part of the anion or part of the cation? Hittorf and Len $z^{1}$ have measured the relative velocity $n$ of the cation in potassium chromate and have found for dilution $v=\mathrm{I} .85, n=0.488(\mathrm{H})$; for $v=2$, $n=0.49(\mathrm{~L})$; for $v=4, n=0.53(\mathrm{~L})$; for potassium bichromate $v=4.3, n=0.498(\mathrm{H})$. Walden ${ }^{2}$ has found the following values for the molectular conductivity $(\mu)$ of the various chromates at the dilutions named (v).

\begin{tabular}{|c|c|c|c|c|}
\hline & $\mathrm{O} .5 \mathrm{~K}_{2} \mathrm{CrO}_{4}$ & $0.5 \mathrm{~K}_{2} \mathrm{Cr}_{2} \mathrm{O}_{\tau}$ & $\mathrm{O} .5 \mathrm{~K}_{2} \mathrm{Cr}_{3} \mathrm{O}_{10}$ & $\mathrm{H}_{2} \mathrm{CrO}_{4}$ \\
\hline$v$ & $\mu$ & $\mu$ & $\mu$ & $\mu$ \\
\hline 32 & I 2 I. 2 & I 14.4 & 275.4 & 354.5 \\
\hline 64 & I 27.5 & I I 6.6 & 283.0 & 358.2 \\
\hline I 28 & $132 . \mathrm{I}$ & I I 7.5 & 285.9 & 360.6 \\
\hline 256 & 136.0 & I I 8.0 & 286.0 & 360.1 \\
\hline 5 I & 138.4 & I18.6 & 283.4 & $358 . I$ \\
\hline 1024 & 140.5 & 120.8 & 278.2 & 354.2 \\
\hline
\end{tabular}

Ostwald ${ }^{3}$ pointed out that chromic acid is weaker than carbonic, that it gives very small depressions of the freezing-point and that its salts are of the type $\mathrm{M}_{2} \mathrm{Cr}_{2} \mathrm{O}_{7}$; these reasons combined with the results of Walden have caused him to ascribe to chromic acid in solution the formula $\mathrm{H}_{2} \mathrm{Cr}_{2} \mathrm{O}_{7}$. In direct oppo-

"Ostwald: "Lehrbuch," 2, I, 607.

${ }^{2}$ Zeit. phys. Chem., 2, 7I (1888).

${ }^{3}$ Ibid., 2,78 ( 1888 ). 
sition to Ostwald, Abegg and Cox, ${ }^{1}$ consider that in a bichromate solution there are present few $\mathrm{Cr}_{2} \mathrm{O}_{7}$ ions, and that the ions are formed from the monochromate which being a weak acid hydrolyzes; also that $\mathrm{CrO}_{3}$ exists free in the solution. The greater conductivity of the monochromates as compared with the bichromates which hold the same amount of alkali, they explained by assuming that the chromate ion moves more rapidly than the bichromate ion, and that in the case of the monochromate the hydroxyl ion produced in the hydrolysis increases the conductivity. The first assumption is not in accord with the results of Hittorf and Lenz as recorded above.

Connected with the study of constitution is the heat of neutralization. Thomsen found that when chromic acid was neutralized by one, two or four molecules of sodium hydrate, there was a heat evolution of $13100,24700,25200$ calories, whereas for sulphuric acid similar experiments gave I4600, 3 I000 and 3 I000 calories. On the other hand, chromic acid when treated with a stronger acid such as hydrochloric forms a chromic salt; in solution, therefore, it should be ionized the same way as other weak bases.

Is the evidence as thus summed up absolutely conclusive that the constitution of chromic acid in solution is well known, that the chromium always exists as part of the anion, and that at no time the $\mathrm{CrO}_{3}$ dissociates to form hexavalent chromium cations?

(b) Previous Work on the Electrolysis of Chromic Acid.Since the anodic oxidation of chromic salts to chromates is a work of commercial importance, considerable work has been done upon it; in regard to the reactions at the cathode, the statements made are very unsatisfactory. The first one to under. take the electrolysis of the acid seems to have been Geuther. ${ }^{2}$ His electrolyzing vessel was provided with sealed-in platinum electrodes; working with a current from four Bunsen elements, he examined the gas evolution at the electrodes and the amount of the metal deposited, while the concentration of the solutions

\footnotetext{
${ }^{1}$ Zeit. phys. Chem., 48, 725 (1904).
}

2 Liebig's Ann., 99, 314 (1856). 
was varied. He was able to weigh the chromium which he obtained. One set of his results is given in Table I. The I which he thought he was using is practically the tenth part of an ampere, since calculation (Table I) indicates that $0.780 \mathrm{I} I$ for II 77 seconds produces 7.650 ingms of oxygen, or that 8 grams would require 96017 coulombs. Working on the assumption that 96540 coulombs will deposit. 8 grams of oxygen, we have, in order to determine the efficiencies, added the last column. The nomenclature is that used by Geuther. In the table, the numbers refer to his experiment; the solution used is then given; I refers to the current intensity (approximately tenths of amperes); $\mathrm{D}$ to the time in seconds; $\mathrm{Cr}$ to the weight in milligrams of the chromium found; $\mathrm{O}_{\mathrm{vol}}$ to the volume in $\mathrm{cc}$ of oxygen in the electrolyzing vessel reduced to $0^{\circ}$ and $760 \mathrm{~mm}$, and $\mathrm{O}$ to the weight in milligrams of this gas; $\mathrm{O}_{\mathrm{I}}$ to the calculated weight of oxygen which should have been evolved by the current; $\mathrm{H}_{\mathrm{Vol}}$ to the volume in $\mathrm{cc}$ of hydrogen in the electrolyzing vessel reduced to $0^{\circ}$ and $760 \mathrm{~mm}$, and $\mathrm{H}$ to the weight of this gas; $\mathrm{H}_{\mathrm{I}}$ to the weight of the hydrogen corresponding to the current passed. The percentage of hydrogen deficiency computed from the hydrogen columns (the deposition of the metal being ignored) is given in the $H_{D}$ column. The last column gives the number of grams of chromium which would be deposited by 96540 coulombs.

The current densities employed must have been very great since platinum wires were used; but for solutions of practically the same concentration, this may have been maintained suffciently constant. Other results obtained by Geuther indicated that at the anode, more oxygen was evolved than corresponded to the Faraday law. This is indicated in the following table, the numbering of the original article being retained; the numbers in the first column refer to the solutions of Table I. The, last column is our own addition to Geuther's table.

Some other results obtained by Geuther are to be noted. He states that the amount of metal deposited seems to reach a maximum when the solution contains one part of chromic acid to ten parts of water; also that the amount of metal deposited 


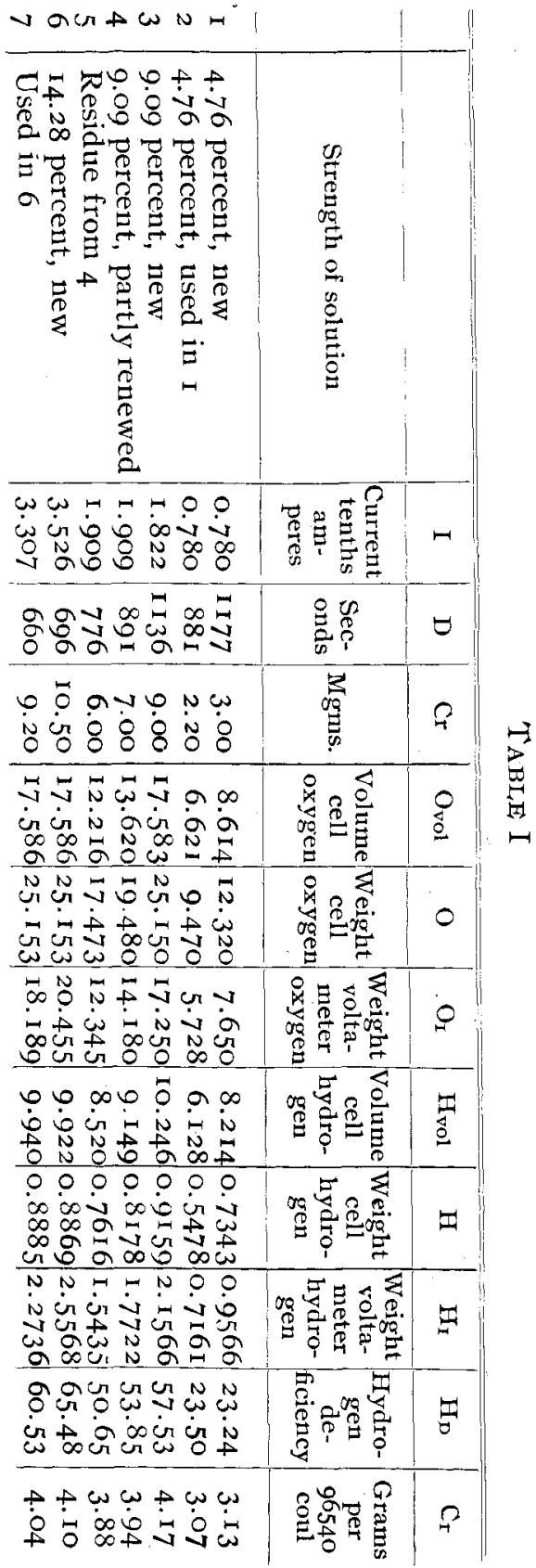


TABLE II.

\begin{tabular}{|c|c|c|c|c|c|c|c|c|}
\hline & I & D. & Ovol & $\mathrm{O}_{\mathrm{I}}$ & $\mathrm{O}$ & $O \div I D$ & Excess & Excess \\
\hline 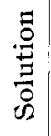 & $\begin{array}{l}\text { Current } \\
\text { tenths of } \\
\text { amperes }\end{array}$ & $\begin{array}{l}\text { Sec- } \\
\text { onds }\end{array}$ & $\begin{array}{c}\text { Volume } \\
\text { cell } \\
\text { oxygen }\end{array}$ & $\begin{array}{l}\text { Weight } \\
\text { cell } \\
\text { oxygen }\end{array}$ & $\begin{array}{l}\text { Weight } \\
\text { volta- } \\
\text { meter } \\
\text { oxygen }\end{array}$ & $\begin{array}{c}\text { Mgms } \\
\text { oxygen } \\
\text { per } \\
\text { coulomb }\end{array}$ & $\begin{array}{c}\text { Oxygen } \\
\text { in } \\
\text { mgms }\end{array}$ & $\begin{array}{c}\text { Percent } \\
\text { of } \\
\text { oxygen }\end{array}$ \\
\hline \multirow[t]{4}{*}{3} & I. 822 & 282 & 3.796 & $5.4 \mathrm{I} 8$ & 4.283 & 0.01056 & I. I 35 & 29.9 \\
\hline & -- & 579 & 8.329 & I I.9I 3 & 8.793 & 0.01129 & 3.210 & 38.53 \\
\hline & - & 1017 & 15.250 & 21.810 & I 5.440 & 0.01177 & $6.37^{\circ}$ & 41.78 \\
\hline & - & $\operatorname{l} 136$ & I 7.583 & 25.150 & 17.250 & 0.01215 & 7.900 & 44.92 \\
\hline \multirow[t]{3}{*}{4} & 1.909 & 271 & 3.797 & 5.431 & 4.312 & 0.01050 & I. II9 & 29.47 \\
\hline & - & 570 & 8.330 & II.9I4 & 9.070 & 0.01095 & 2.844 & 34.15 \\
\hline & 一 & $89 \mathrm{I}$ & 13.620 & $19.480^{\circ}$ & 14.180 & 0.01 I 45 & 5.300 & $38.9 \mathrm{I}$ \\
\hline \multirow[t]{3}{*}{5} & 1.909 & 264 & 3.813 & 5.453 & 4.201 & 0.01097 & I. 252 & 32.60 \\
\hline & - & 567 & 8.365 & I I. 965 & 9.022 & 0.01105 & 2.942 & 35.18 \\
\hline & - & 776 & I 2.216 & 17.473 & 12.345 & 0.01179 & 5. 128 & 42.00 \\
\hline \multirow[t]{4}{*}{6} & 3.526 & I 72 & 3.799 & 5.435 & 5.055 & 0.00896 & 0.380 & 10.00 \\
\hline & - & 355 & 8.338 & I 1.925 & I0. 433 & 0.00953 & I. 492 & 17.89 \\
\hline & - & 477 & I I. 780 & r6.848 & 14.020 & 0.01002 & 2.828 & $24.0 \mathrm{I}$ \\
\hline & - & 696 & 17.586 & 25.153 & 20.455 & 0.01025 & 4.698 & 27.98 \\
\hline \multirow[t]{4}{*}{7} & 3.307 & $16_{3}$ & 3.799 & 5.435 & $4.49^{2}$ & 0.01008 & 0.943 & 24.26 \\
\hline & - & 337 & 8.338 & I 1.925 & 9.287 & 0.01070 & 2.638 & 31.63 \\
\hline & - & 454 & 17.780 & I 6.848 & 12.512 & 0.01122 & 4.336 & 24.38 \\
\hline & 一 & $660^{\prime}$ & 17.586 & 25.153 & 18. I89 & 0.01152 & 6.964. & $39.6 I$ \\
\hline
\end{tabular}

diminishes as the current is passed. The more concentrated the solutions the greater is the reduction; the further the electrolysis has been carried, the less is the reduction. The amount of chromium deposited stands in direct relation to the hydrogen deficiency.

The theoretical views expressed by Genther (combined with the novelty of his results) caused Buff ${ }^{1}$ to undertake the electrolysis of chromic acid. The electrolysis was performed in a snall vessel into which platinum wires were sealed; the gases were collected in U-tubes. Four Bunsen elements supplied the current. With a 5.I3 percent acid solution, he performed experiments which are recorded in Table III. In the last two experiments, sulphuric acid was added.

Buff was successful neither in obtaining a deposit of metallic chromium nor in noting an excess of oxygen at the anode. $\mathrm{He}$

1 Liebig's Ann,, Ior, I (1857). 
TABLE III

\begin{tabular}{|c|c|c|c|c|c|c|c|}
\hline & $\begin{array}{l}\text { Time } \\
\text { mint. } \\
\text { tes }\end{array}$ & $\begin{array}{l}\text { Degrees } \\
\text { tan. } \\
\text { galv. }\end{array}$ & $\begin{array}{c}c c \\
\text { oxygen } \\
\text { evolved }\end{array}$ & $\begin{array}{l}\mathrm{cc} \\
\text { hydrogen } \\
\text { evolved }\end{array}$ & $\begin{array}{l}\text { Hydrogen } \\
\text { in } \\
\text { volta- } \\
\text { meter }\end{array}$ & $\begin{array}{c}\text { Percent- } \\
\text { age } \\
\text { evolution } \\
\text { hydrogen }\end{array}$ & Electrodes \\
\hline I & 20 & I.5 & $25 \cdot 4$ & I9.0 & $5 \mathrm{I} .5$ & 36.9 & Platinum wires \\
\hline 2 & 6 & 7.9 & $35 \cdot 3$ & 32.5 & 73.6 & 44. I & Platinum wires \\
\hline 3 & 6 & $7 \cdot 55$ & 35.1 & 7.4 & 70.0 & 10.5 & I. $5 \times$ I inch \\
\hline 4 & 5 & 6.8 & - & 2.2 & 50.8 & $4 \cdot 3$ & I.5 $\times$ I inch \\
\hline 5 & 4 & 9.65 & - & 7.2 & 62.0 & I6. I & $1.5 \times$ I inch \\
\hline 6 & 4 & 9.4 & - & 0.6 & 57.2 & I.O & $1.5 \times I$ inch \\
\hline 7 & 5 & I 2.8 & - & I. 6 & 61.2 & 2.6 & $1.5 \times \mathrm{I}$ inch \\
\hline
\end{tabular}

therefore claimed that the results of Geuther were unreliable, basing this on the criticism that the galvanometer used by the latter had not been calibrated against the hydrogen voltameter, whereas Buff's results were obtained by use of a gas voltameter. The reply of Genther does not insist upon the reliability of his experimental work. He states: "Was die Electrolyse der Chromsäure betrifft, so hat Buff gezeigt dass sich bei meinem Messungen der Stromintensität, welche mit einer Tangentenboussole ausgeführt werden, deren Magnetnadel wohl nicht die zu diesen Messungen erforderliche Empfindlichkeit besessen haben mag, ein Irrthum eingeschlossen haben müsse. Dadurch wurden allerdings due Gründe beweislos, welche aus den Messungen abgeleitet worden waren, nicht aber die anderen dort angeführten.' The subject seemed closed to discussion by a second paper from Buff and the complete experimental work of Geuther utterly discredited. ${ }^{3}$

In 1878 Morges $^{4}$ stated that chromic acid in dilute solution was reduced to chromium chromate by the current. Bartoli and Papasogli ${ }^{5}$ electrolyzed the acid making use of graphite electrodes; again the statement was made that metallic chromium was obtained.

\footnotetext{
${ }^{1}$ Liebig's Ann., 109, 29 (1858).

${ }^{2}$ Ibid., I10, 278 ( 1858 ).

"Le Blanc: "Darstellung des Chroms," p. 9 I. (1871).

${ }^{4}$ Comptes rendus, 87, I5 (I878); compare also Favre, Ibid., 73, 89o, 936

${ }^{5}$ Gazz. chim. Ital., 13, 47 (1883).
} 
In I894, Placet and Bonnet were granted an American patent, ${ }^{1}$ the specifications of which are, in all probability, more complete than those of the earlier European patents. They state that of the electrolytes which they use, "the most important of these compounds is chromic acid, either the commercial" acid, or chromic acid obtained from chromate or bichromate of an alkali metal." They also patented the use of most of the soluble chromic salts. To vary the shade of the metal, they added small amounts of other acids. The concentrations of the electrolytes used are given, but the only clue to the other experimental conditions which they may have used is indicated in another of their patents ${ }^{3}$ where high current densities are suggested. Their statement is: "By increasing the pressure an electric current may be passed, having an illimitable power. Under these conditions a composite body does not exist which may not be decomposed." As to the yields, the American patent states: "By our processes, as hereinafter set forth, we obtain electrodeposited chromium of great purity in coherent masses of sufficient size for various industrial uses, and of various colors as may be desired. In these processes, we use salts and compounds of chromium which heretofore have never been used or proposed for use for the purpose in view, and from which in the manner hereinafter pointed out metallic chromium is produced in sufficient quantity and with sufficient economy to constitute an industrial process, very different from the result of laboratory experiments by which the production of minute specimens of metallic chromium has been hitherto attempted."

In his monograph on chromium, Le Blanc devotes many pages to a review of the patents of Placet and Bonnet, and finally in conclusion states that either the metal cannot be obtained in the way indicated in the patents or that at least all of the necessary conditions are not there given in detail. ${ }^{5}$ He cites the fact that Cowper-Coles, Ferée, and Shick had been unsuccessful in

\footnotetext{
${ }^{1}$ U. S. Patent, 526144, September I8 (1894).

2 Italics inserted by the authors of this paper.

${ }^{3}$ English patent, 19344 ( 1890 ).

4 "Darstellung des Chroms," pp. 3-17.

${ }^{5}$ Compare Jour. Phys. Chem., 9, 235 (I905).
} 
their attempts to reproduce the conditions indicated in the patents. In the "Jahrbuch der Electrochemie," I, I74, the criticism of the Placet-Bonnet patent is: "Nach der erwähnten Vorschriften ist aber eine Fabrication nie möglich." Ahrens states: "Die Patentschrift ist indessen so abgefasst dass, auf dem darin angegebenen Wege, Chrom unmöglich fabriziert werden kann."

In I899, Reese ${ }^{2}$ electrolyzed chromic acid examining the effect produced on the electrolyte by the gases evolved. As an electrolyzing vessel he used a burette; the cathode was put at the bottom so that the rising hydrogen passed through a long column of the acid. With pure acid of normal concentration, he found no reduction even after an electrolysis of twenty-four hours; when, however, traces of sulphate or sulphuric acid were present, reduction was quickly effected "but there was always a limit reached when no further reduction took place." Potassium bichromate behaved in exactly the same way as the acid. Neither the current density employed nor other important experimental details are given. The results, however, might at first sight seem to be in direct opposition to those obtained by Geuther and Buff, both of whom found considerable reduction.

This historical review raises several questions: (I) May metallic chromium be deposited in the electrolysis of chromic acid solutions? (2) If so, under what conditions and what is the current yield? (3) Why is there such a great diversity of experimental results, and conclusions? (4) Is there reduction at the cathode or oxidation at the anode? (5) Is the statement of Geuther in regard to the excess of oxygen at the anode correct?

(c) Chemical Reactions of Chromic Acad.-In every electrochemical study, an accurate knowledge of the oxidation and reduction possibilities of the compounds involved is necessary. This is especially needed in the case of the compounds which are considered in this paper.

Chromic acid is a very powerful oxidizer, or in other words

1 "Handbuch der Electrochemie," p. 442.

${ }^{2}$ Am. Chem. Jour., 22, 162 (1899). 
it is very easily reduced; in fact, even hydrogen ${ }^{1}$ will effect the reduction of saturated solutions. Catalytic agents such as platinum would probably accelerate this reduction. The more pure the acid, the less readily it is reduced; this is shown by the work of Gawalovski ${ }^{2}$ who found that pure acid reacts with alcohol very slowly, but that the addition of an acid accelerated the reaction very decidedly. This is another confirmation of the results of Bancroft who showed that the addition of an acid raised the potential of an oxidizer. Another illustration of this principle where chromic acid is again involved is the Grove cell where zinc and graphite electrodes are used in a mixture of sulphuric and chromic acid. With the low current density at which the cell is used, the acidified chromic acid acts as an almost ideal depolarizer since by the addition of the sulphuric acid, its oxidation potential has been very much increased; the result is the formation of chromic sulphate as the cell is discharged.

The reverse operation-the oxidation of chromic salts to chromates-may be effected by the use of oxidizers such as manganese or lead peroxide, potassium permanganate or chlorine in acid solutions.

(d) Electrochemical Relations.-Chromium is an element which shows at least three different valencies; the electrochemical relations have been worked out by Luther $^{3}$ who, assuming the potential -0.56 for the Ostwald normal electrode, gives the following values :

Potential of metallic chromium against its divalent salts $=0.3$ volt. Potential of metallic chromium against its trivalent salts $=0.2$ volt. Potential of metallic chromium against its hexavalent salts $=-0.9$ volt.

The question of the potential of the metal in solutions of chromium chromate was not considered. The theoretical method employed by Luther was criticized by Hittorf ${ }^{4}$ on the ground

${ }^{1}$ Ludwig: Liebig's An11., 162, 47 (1872).

2 Zeit. analyt. Chem., 17, 179 (1878).

${ }^{3}$ Zeit. phys. Chem., 36, 389 (1900).

${ }^{4}$ Zeit. Elektrochemie, 7, 257 (1900). 
that chromium in chromic acid was not a reversible electrode since from the chromate solutions it was impossible to obtain the metal; while Luther admitted this last fact, he claimed that it did not affect the conclusions which he had drawn.

Hittorf has shown that chromium, when used as anode, goes into solution with different valencies according to the condition ${ }_{S}$ used. The electromotive forces involved are illustrated by the combination chromium, potassium chloride, sodium nitrate, silver nitrate, silver. When active chromium was used, Hittorf found an electromotive force of I.006 volts, silver being cathode. This value increased as the temperature rose, finally forming a constant element. At the lower temperature, the rate of solution showed the metal hexavalent while at the higher it tended to become divalent. It seems very probable both from the work of Hittorf, and from some experiments that we ourselves have made that the changes of valency are not discontinuous but that systematic study would show all stages of valence (anodic efficiency) lying between hexavalent and divalent.

The fact that the metal goes into solution at the anode as a hexavalent ion may be explained by the modern theory of the voltaic cell thus-the metal has a solution tension which is determined by the presence in the solution of hexavalent chromium ions. As shown above, Luther has calculated this value as -0.9 volt; nevertheless in the inconclusive work on the constitution of chromic acid which at the beginning of this paper we have quoted, there was no mention whatever of the possibility of the presence of hexavalent chromium ions in the solution. The nearest approach to such a suggestion was made by Abegg and Cox who claimed that free $\mathrm{CrO}_{3}$ exists in the solution.

To explain the results of Hittorf and Luther, the assumption must therefore be made that some hexavalent chromium ionscations-exist in the solution of chromic acid. This assumption would be given some support if proof could be adduced that

1 This is probably an illustration of a general principle that rise of tem. perature favors the formation in the solution of compounds in which the lissolving anode shows its lower valency. We may, later examine the limitations of this suggestion in relation to the heat and electrical energies involved in the changes of valence. 
chrominum can be deposited from chromic acid; and while it rarely happens that a cathode reaction is the exact converse of the anode reaction, nevertheless some information as to the action of reversible electrodes should be obtained from the cathode reactions.

We pass at once therefore to the results obtained in the actual electrolyses of chromic acid.

(e) Preliminary Electrolyses.-As electrolyte there was selected a chromic acid which contained considerable sulphate as impurity. This was washed repeatedly with concentrated nitric acid and dried in an air-bath at $160^{\circ}$. The electrodes which were used throughout the investigation were platinum wires 0.4 $\mathrm{mm}$ in diameter, $30 \mathrm{~mm}$ long; the area of these was approximately 0.004 square decimeter. With various concentrations of the chromic acid, we now made a series of electromotive forcecurrent measurements. For two reasons these results are not given: a very careful analysis of the acid had not been made and hence it is impossible to reproduce the measurements, and secondly, the runs were not carried far enough to determine with exactness the exact decomposition voltages. Nevertheless chromium deposits were obtained; the measurements gave, therefore, very rough indications as to the current densities which were necessary. For solutions ranging in concentration from one to fifty percent acid, the current density at which an instantaneous deposition of metal was observed was about 80 amperes per sq. $\mathrm{dcm}$. at $I 8^{\circ}$ while twice this density was necessary at a temperature of $90^{\circ}$.

At the lower current densities hydrogen was liberated. The question was at once raised as to the absorption of this gas by the metal. Of a quantity of chromium deposited from chromic acid solution, 0.6979 gram when heated gave $24.6 \mathrm{cc}$ of hydrogen at $t=20^{\circ}, p=75^{\circ} \mathrm{mm}$; as a rough approximation then, one volume of electrolytic chromium had absorbed 250 times its volume of hydrogen. This metal shows then, perhaps, even greater power for absorbing hydrogen than palladium, platinum, iron and nickel.

Chromic acid labeled "C. P., free from sulphate" was now 
obtained from a reputable firm. Again sulphate was found in considerable amounts. Reduction to chloride and precipitations as barium sulphate showed 0.23 percent of free acid; the precipitate was white and lost but little weight on repeated washings with hydrochloric acid. When barium chloride was added to the chromic acid solution strongly acidified with hydrochloric acid, the percentage of sulphate found was only o.I4 percent. However more of the sulphate precipitated from this solution after the filtrate had stood for several days, the total percentage increasing to 0.20 percent of sulphuric acid impurity. Nitric acid was also present in minute amounts.

The solutions were electrolyzed in a well-stoppered cylinder which was kept in a bath of constant temperature. The ammeter readings served only for a rough adjustment, since an alkaline nickel voltameter was always kept in circuit. The gases from the voltameter were analyzed repeatedly to check the accuracy of the results obtained. The cathode deposit was weighed after careful washing and drying in the air-bath. The gases evolved from the cells were collected in a Hempel burette and then analyzed for oxygen, using the alkaline pyrogallol and phosphorus absorption methods.

With temperature constant, but varying current, a run was now made using $50 \mathrm{cc}$ of a 14.28 percent acid solution. This concentration was chosen in order to allow comparisons with the work of Geuther; most of the tables refer therefore to this strength. The results are given in Table IV, which, as in all subsequent tables, is arranged as follows: The first column gives the number of the experiment, the second the time in seconds, the third the number of $\mathrm{cc}$ of gas found in the voltameter, the fourth the $c c$ of gas in the cell. The number of $\mathrm{cc}$ of oxygen found in this cell gas is shown in the next column, while the difference between the figures in the fourth and fifth columns gives the number of $\mathrm{cc}$ of hydrogen recorded in the sixth column. The percentage deficiency of hydrogen given in the seventh column is calculated on the assumption that no other decomposition had taken place. The eighth row gives the number of milligrams of the metal deposited. The last row which is to be found only in Table IV indicates the ammeter reading. 
For all other series, the temperature and current were kept quite constant.

\section{TABLE IV}

\begin{tabular}{|c|c|c|c|c|c|c|c|c|}
\hline No. & Seconds & $\begin{array}{l}\text { Volt. } \\
\text { gas }\end{array}$ & $\begin{array}{l}\text { Cell } \\
\text { gas }\end{array}$ & $\begin{array}{l}\text { Cell } \\
\text { oxy- } \\
\text { gen }\end{array}$ & $\begin{array}{c}\text { Cell } \\
\text { bydro } \\
\text { gen }\end{array}$ & \begin{tabular}{|c} 
Per- \\
cent \\
reduc \\
redion \\
tion
\end{tabular} & $\mathrm{Cr}_{\mathrm{Cr}}^{\mathrm{Mgms}}$ & $\begin{array}{l}\text { Am- - } \\
\text { peres }\end{array}$ \\
\hline & & 80.2 & 6.4 & & & 6.9 & 0.0 & O. II \\
\hline & & & .2 & 28.0 & 3.2 & 22.7 & 7.8 & \\
\hline & & & & - & - & - & 8.0 & 1.20 \\
\hline & 36 & 87.0 & 72.8 & 29.0 & 43.8 & 26.2 & $9 \cdot 7$ & 1.20 \\
\hline & & & & & & 5.9 & & 0.2 \\
\hline & 102 & 89.0 & 70.0 & 29.6 & 40.4 & 31.9 & 10.8 & \\
\hline & & & & & & & 9.9 & $1.7^{\circ}$ \\
\hline & & +2 & 1.4 & 3 I. 5 & 49.9 & 20.8 & 9. I & 1.9 \\
\hline
\end{tabular}

It will be noted that for a current of 0.1 I ampere (area of anode and cathode in every case equals $0.004 \mathrm{sq}$. dcm.) there was a slight reduction but no deposition of metal. Increase of current density caused greater reduction and some metal deposition. Thereafter in most of the runs, efficiency in reduction is practically synonymous with efficiency in metal deposition.

A run was now made to ascertain how the efficiency varied with the time of electrolysis when the temperature and current were constant. Between experiments (5) and (6), (7) and (8) electrolysis was continued for some time during which no analyses were made. Results are given in Table V.

The metal deposited in (I) Table $\mathrm{V}$ weighed 8 milligrams; the cathode deposit was not again determined until (IO) and (II) when in each case $2 \mathrm{mgms}$ was found. This series shows that the percentage reduction as well as the metal deposition fall off as the run was continued.

(f) Results with Pure Acid.-Reese had stated that with pure chromic acid he was unable to get any reduction whatever. We therefore obtained a chromic acid from Merck which by the Krauch test showed no impurities. Analysis showed that there was present 0.01 percent of free sulphuric acid, and very slight traces of nitric acid and alkali metal. While recrystallization would undoubtedly have given us an acid still more pure, it 


\section{TABLE V}

14.28 percent acid; cylinder electrolyzer; current $=1.2$

amperes; $t=22^{\circ} \pm 2^{\circ}$

\begin{tabular}{|c|c|c|c|c|c|c|c|}
\hline No. & Seconds & $\begin{array}{l}\text { Volt. } \\
\text { gas }\end{array}$ & $\begin{array}{l}\text { Cell } \\
\text { gas }\end{array}$ & $\begin{array}{l}\text { Cel1 } \\
\text { oxy- } \\
\text { gen }\end{array}$ & $\begin{array}{c}\text { Cél1 } \\
\text { hydro } \\
\text { gen }\end{array}$ & $\begin{array}{c}\text { Per- } \\
\text { cent } \\
\text { reduc- } \\
\text { tion }\end{array}$ & $\underset{\mathrm{Cr}}{\mathrm{Mgms}}$ \\
\hline $\mathrm{I}$ & 354 & 84.6 & $7 \mathrm{I} . \mathrm{I}$ & 28.2 & 41.9 & 25.7 & 8.0 \\
\hline 2 & $35 \mathrm{I}$ & 84.0 & 67.4 & 28.0 & 39.4 & 29.6 & - \\
\hline 3 & 360 & 83.0 & 66.5 & 27.6 & 38.9 & 29.6 & - \\
\hline 4 & 380 & 87.0 & 70.3 & 29.0 & $4 \mathrm{I} \cdot 3$ & 28.8 & $-m$ \\
\hline 5 & 340 & 85.5 & 68.9 & 28.5 & 40.4 & $29 . I$ & - \\
\hline & 1800 & - & - & - & - & - & - \\
\hline 6 & 362 & 85.8 & 69.4 & 28.6 & 40.8 & 28.6 & - \\
\hline & 3600 & - & 一 & - & - & 一 & 一 \\
\hline 7 & 345 & 84.4 & 77.5 & 28. I & 49.4 & I 2.2 & 一 \\
\hline & 4200 & - & & - & - & & - \\
\hline 8 & 360 & 87.3 & 82. I & $29 . I$ & 53.0 & 8.9 & 一 \\
\hline 9 & 382 & 87.2 & 82.8 & 29.0 & 53.8 & 7.2 & 一 \\
\hline IO & 365 & 83.6 & 79.4 & 27.9 & $5^{1.5}$ & 7.5 & 2.2 \\
\hline I I & 343 & 82.6 & 79.2 & 27.5 & 5 I.7 & 6.1 & 2.2 \\
\hline
\end{tabular}

would have required the greatest care and a long time to obtain by the necessarily slow crystallization an acid much purer. The probabilities are that the acid is at least as pure as any that has been used in conductivity or electrolytic work. In all our subsequent electrolyses we have therefore used this acid.

When a 14 percent solution of this acid was electrolyzed for two days with a very low current derived from a two-volt circuit, no reduction was observed and no metal was deposited. A current-electromotive force curve showed the decomposition voltage at which metal was observed as 2.31 volts; hydrogen was evolved from I. 6 volts or even lower. The electrolyzing cell was connected to a four-volt circuit; metal deposition and darkening of the solution were noticed almost immediately when the circuit was closed. It seems very probable, therefore, that Reese used low currents for his electrolyses and that he was below the point at which metal deposition was to be expected.

For the experiments cited in the last paragraph and in all subsequent work, we have made use of a glass-stoppered glass cell in order that the possible reduction of the chromic acid by organic matter which might come from a rubber stopper should 
be completely eliminated. The cathode was fastened into a ground glass stopper which could be readily cleaned and weighed. The anode was sealed in at the bottom. The gases evolved were led through a side arm into a gas burette. The small content of the cell $(3 \mathrm{cc})$ enables one to control the temperature very readily, while another advantage is that a run may be carried to a final stage in a very short time. The small gas space over the solution also allows one to reproduce conditions with great exactness.

With this purer acid, and the glass electrolyzer, runs were made to find the effect of temperature; the current used, 0.5 ampere, corresponds to a density at anode and cathode of 125 amperes per square decimeter. The results obtained at $20^{\circ}$ are given in Table VI, at $90^{\circ}$ in Table VII.

\section{TABLE VI}

I 4.28 percent acid; glass electrolyzer; current $=0.5 \mathrm{amp} ; \mathrm{D}$

\begin{tabular}{|c|c|c|c|c|c|c|c|}
\hline No. & Seconds & $\begin{array}{l}\text { Volt. } \\
\text { gas }\end{array}$ & $\begin{array}{l}\text { Cell } \\
\text { gas }\end{array}$ & $\begin{array}{l}\text { Cell } \\
\text { oxy- } \\
\text { gen }\end{array}$ & $\begin{array}{c}\text { Cell } \\
\text { bydro- } \\
\text { gent }\end{array}$ & $\begin{array}{l}\text { Per- } \\
\text { cent } \\
\text { reduc. } \\
\text { tion }\end{array}$ & $\underbrace{\mathrm{Mgmm}}_{\mathrm{Cr}}$ \\
\hline I & 960 & 96.2 & 89.8 & 31.9 & 57.9 & 9.8 & 3.6 \\
\hline 2 & 960 & 94.5 & 92.8 & $3 I .0$ & 61.8 & 1.9 & 0.9 \\
\hline 3 & 780 & 79.5 & 79.5 & 26.7 & $5^{2.9}$ & 0.2 & 0.4 \\
\hline \multirow[t]{2}{*}{4} & 960 & 92.4 & 91.0 & 30.8 & 60.2 & 2.2 & 0.7 \\
\hline & 4800 & - & - & - & - & - & - \\
\hline 5 & 1020 & 93.9 & 93.0 & 31.0 & 62.0 & I.O & 0.4 \\
\hline
\end{tabular}

14.28 percent acid ; current $=0.5 \mathrm{amp} ; \mathrm{D}$ anode $=\mathrm{D}$ cathode $=125 ; t=90^{\circ}$

\begin{tabular}{|c|c|c|c|c|c|c|c|}
\hline No. & Seconds & $\begin{array}{l}\text { Volt. } \\
\text { gas }\end{array}$ & $\begin{array}{l}\text { Cel1 } \\
\text { gas }\end{array}$ & $\mid \begin{array}{c}\text { Cell } \\
\text { oxy- } \\
\text { gen }\end{array}$ & $\begin{array}{c}\text { Cell } \\
\text { hydro } \\
\text { gen }\end{array}$ & $\begin{array}{l}\text { Per- } \\
\text { cent } \\
\text { reduc- } \\
\text { tion }\end{array}$ & $\int_{\mathrm{Cr}}^{\mathrm{Mgmn}}$ \\
\hline $\mathbf{I}$ & & 90.6 & 90 & 30.2 & 60.3 & 0.2 & 0.2 \\
\hline 2 & $\begin{array}{r}840 \\
3600\end{array}$ & 90.1 & 89.0 & 29.8 & 59.2 & I. 2 & 0.3 \\
\hline 3 & $\begin{array}{l}1080 \\
1080\end{array}$ & 98.4 & 97.I & 31.7 & 65.4 & $\stackrel{0.3}{-}$ & $\stackrel{0.2}{-}$ \\
\hline & 840 & 97.9 & 96.2 & 32.0 & 64.2 & I. 5 & 0.2 \\
\hline
\end{tabular}


It was necessary to stop the series after the fifth run (Table VI) because of the presence of a large amount of an insoluble precipitate.

It will be noticed that in the electrolysis at $20^{\circ}$, metal is deposited from the first and that the reduction and metal deposition decrease as the run continues. Small errors in analysis are of course greatly magnified when dealing with cases showing such little reduction as is here found. At the higher temperature reduction and metal deposition are insignificant.

$(g)$ Effect of Impurities. - Comparison of Tables IV and V with VI indicate that, as was noted in a discussion of the reactions of chromic acid, a slight amount of impurity may have a very noticeable effect on the reduction. Geuther had made his acid from potassium bichromate and sulphuric acid, while Buff and Reese made use of C. P. acid. None of the chemists who have written about the electrolysis of chromic acid have described the methods by which the pure acid may be obtained and tested. It is a long and difficult operation to free it from the sulphuric acid used in its manufacture and the sodium sulphate which occurs as the bye-product, or the nitric acid which is used in freeing from the sulphuric. It seemed possible then that the deliberate addition of impurities might enable one to duplicate the results obtained especially in the cases where the object of the work had been purely commercial, and where under no circumstance would a chemically pure chromic acid have been used.

To the I4.28 percent chromic acid solution was added sulphuric acid in amounts sufficient to make its concentration one percent. The other conditions were the same as had been employed in Table VI, namely $t=20^{\circ}$, current 0.5 ampere. The results are given in Table VIII.

In all cases the metal deposit scaled very badly, and in some cases fell into the solution so that the results are approximations only. A duplicate set of determinations for metal only gave the following numbers in milligrams-I9.x, 20.8, I6.2, I7.3, $0.9,7.8, \mathrm{r} .9$, while in the solution was 20 milligrams of scale deposit. It is at once apparent that the effect of the sulphuric 
TABLE VIII

I 4.28 percent chromic + I percent sulphuric ; current $=$ $0.5 \mathrm{amp} ; \mathrm{D}$ anode $=\mathrm{D}$ cathode $=125 ; t=20^{\circ}$

\begin{tabular}{c|c|c|c|c|c|c|c}
\hline & No.' Seconds & $\begin{array}{l}\text { Volt. } \\
\text { gas }\end{array}$ & $\begin{array}{c}\text { Cell } \\
\text { gas }\end{array}$ & $\begin{array}{c}\text { Cell } \\
\text { oxy- } \\
\text { gen }\end{array}$ & $\begin{array}{c}\text { Cell } \\
\text { hydro- } \\
\text { gen }\end{array}$ & $\begin{array}{c}\text { Per- } \\
\text { cent } \\
\text { reduc } \\
\text { tion }\end{array}$ & Mggms \\
\hline Cr
\end{tabular}

acid has been to increase the reduction and the metal deposition to a very great extent. In fact, in the runs recorded in Table VIII and its duplicate, one-half of the total chromum content of the solution was removed as metal, and even then the limit had not been reached. As before noted, the reduction fell off as the run was continued; neither oxygen excess nor ozone formation has been observed.

The platinum anode was now replaced by a lead anode of the same area and a run made under conditions identical with (2) of Table VIII. As was to be expected there was a greater deficiency of oxygen while the reduction was only 55.4 percent in place of 62.7 percent.

A solution was now made up which contained 14.28 percent of chromic + I percent sulphuric acid + I percent potassium sulphate. It was electrolyzed under conditions identical with those used in VI and VIII. The results are given in Table IX.

In runs $I$ and 2 the metal scaled very badly; from 3 to 6 the metal was black. The first run shows great reduction, high metal deposition (at the rate of 4.6 grams metal per 96540 coulombs) and considerable oxidation; as the run continues, the reduction and metal deposition drop off very considerably while oxidation efficiency decreases more slowly.

To the I 4.28 percent chromic acid was now added potassium chromate to make a $I$ percent solution in respect to the chro- 


\section{TABLE IX}

I 4.28 percent chromic + I per cent sulphuric + I percent potassinm sulphate current $=0.5$ amp $; \mathrm{D}$ anode $=\mathrm{D}$ cathode $=$ I25; $t=20^{\circ}$

\begin{tabular}{|c|c|c|c|c|c|c|c|}
\hline No & Seconds & $\begin{array}{l}\text { Volt. } \\
\text { gas }\end{array}$ & $\begin{array}{l}\text { Cell } \\
\text { gas }\end{array}$ & $\begin{array}{l}\text { Cell } \\
\text { oxy- } \\
\text { gen }\end{array}$ & $\begin{array}{c}\text { Cell } \\
\text { hydro } \\
\text { gen }\end{array}$ & $\begin{array}{l}\text { Per- } \\
\text { cent } \\
\text { reduc- } \\
\text { tion }\end{array}$ & Mgrns \\
\hline I & 900 & 93.5 & 44.2 & 25.4 & I8.8 & 69.8 & 22.6 \\
\hline \multirow[t]{2}{*}{2} & 780 & 87.7 & 45.8 & 27.6 & I 8.2 & 68.8 & I 6.8 \\
\hline & 4500 & - & - & - & - & - & - \\
\hline \multirow[t]{3}{*}{3} & 900 & 90.3 & 85.7 & 27.7 & 58.0 & 3.6 & 0.5 \\
\hline & 4500 & -- & - & - & - & & \\
\hline & 870 & 93.2 & 91.0 & 29.5 & $6 \mathrm{II} .5$ & 0.9 & 0.9 \\
\hline & 960 & 98.0 & 95.8 & & 64.6 & 0.9 & 0.7 \\
\hline
\end{tabular}

mate. The conditions of electrolysis remained constant. The results are given in Table $\mathrm{X}$. The extent of the reduction and the amount of metal deposition is less than was observed in the cases where other substances were added.

\section{TABLE X}

14.28 percent acid + I percent potassium chromate; current $=$ 0.5 amp $; \mathrm{D}$ anode $=\mathrm{D}$ cathode $=\mathrm{I} 25 ; t=20^{\circ}$

\begin{tabular}{|c|c|c|c|c|c|c|c|}
\hline No. & Seconds & $\begin{array}{l}\text { Volt. } \\
\text { gas }\end{array}$ & $\begin{array}{c}\text { Cell } \\
\text { gas }\end{array}$ & $\begin{array}{l}\text { Cell } \\
\text { oxy- } \\
\text { gen }\end{array}$ & $\begin{array}{c}\text { Cell } \\
\text { hydro } \\
\text { gen }\end{array}$ & $\begin{array}{c}\text { Per- } \\
\text { cent } \\
\text { reduc- } \\
\text { tion }\end{array}$ & $\mathrm{Mgms}$ \\
\hline I & 840 & 91.8 & $8 I .4$ & 30.0 & $5 \mathrm{r} \cdot 4$ & 16.0 & 5.2 \\
\hline \multirow[t]{2}{*}{2} & 900 & 97.4 & 90.0 & 3 I. 3 & 58.7 & 9.4 & 2.6 \\
\hline & 5400 & - & - & - & - & - & - \\
\hline \multirow[t]{3}{*}{3} & 1000 & 99.8 & 96.3 & 32.7 & 63.6 & $4 \cdot 3$ & 2.0 \\
\hline & 7200 & - & - & 一 & - & - & - \\
\hline & 960 & $97 \cdot 5$ & 95.7 & 31.7 & 64.0 & 0.4 & 0.6 \\
\hline
\end{tabular}

Nitric acid has also been added to the 14.28 percent chromic acid to form a solution holding 0.5 percent nitric. The results are given in Table XI. The metal was dark colored, but nevertheless fair yields were obtained.

One run was made with hydrochloric acid as an impurity to the extent of I percent. The oxygen and chlorine in this as also in Table XIII were not determined separately. There is 
again to be noted high reduction, high oxidation, and fairly good metal deposition.

\section{TABLE XI}

14.28 percent chromic +0.5 percent nitric; current $=0.5 \mathrm{amp}$;

$\mathrm{D}$ anode $=\mathrm{D}$ cathode $=125 ; t=20^{\circ}$

\begin{tabular}{|c|c|c|c|c|c|c|c|}
\hline No. & Seconds & $\begin{array}{l}\text { Volt. } \\
\text { gas }\end{array}$ & $\begin{array}{l}\text { Cell } \\
\text { gas }\end{array}$ & $\begin{array}{l}\text { Cell } \\
\text { oxy- } \\
\text { gen }\end{array}$ & $\begin{array}{c}\text { Cell } \\
\text { hydro- } \\
\text { gen }\end{array}$ & $\begin{array}{c}\text { Per- } \\
\text { cent } \\
\text { reduc } \\
\text { tion }\end{array}$ & $\underset{\mathrm{Cr}}{\mathrm{Mgms}}$ \\
\hline I & 990 & 94.0 & 76.0 & 31.2 & 44.8 & 284 & 6.8 \\
\hline & $\begin{array}{r}960 \\
3600\end{array}$ & 92.4 & 80.4 & 30.6 & 49.8 & Ig. I & \\
\hline ? & $\begin{array}{r}990 \\
5400\end{array}$ & 95. I & 93.6 & 30.9 & $\mid \begin{array}{c}62.7 \\
-\end{array}$ & I.I & \\
\hline & 960 & 94.2 & 93.8 & 3 I. I & 62.7 & 0.16 & 0.4 \\
\hline
\end{tabular}

TABLE XII

I 4.28 percent chromic + I percent hydrochloric; current $=0.5$ amp $; \mathrm{D}$ anode $=\mathrm{D}$ cathode $=125 ; t=20^{\circ}$

\begin{tabular}{|c|c|c|c|c|c|c|c|}
\hline No. & Seconds & $\begin{array}{l}\text { Volt. } \\
\text { gas }\end{array}$ & $\begin{array}{l}\text { Cell } \\
\text { gas }\end{array}$ & $\begin{array}{l}\text { Cell oxygen and } \\
\text { chlorine }\end{array}$ & $\begin{array}{c}\text { Cell } \\
\text { hydrogen }\end{array}$ & $\begin{array}{l}\text { Per } \\
\text { cent } \\
\text { reduc. } \\
\text { tion }\end{array}$ & $\mathrm{Mgms}$ \\
\hline & 960 & 93.6 & 58.7 & 21.6 & 37.2 & 40.3 & I 5.2 \\
\hline
\end{tabular}

With potassium chloride the results of the first run resemble in a very marked degree those obtained with hydrochloric acid. As in Table $\mathrm{X}$, however, when the run is continued, oxidation, reduction and metal deposition soon cease.

\section{TABLE XIII}

I4.28 percent chromic + I percent potassium chloride ; current $=$ $0.5 \mathrm{amp} ; \mathrm{D}$ anode $=\mathrm{D}$ cathode $=\mathrm{I} 25 ; t=20^{\circ}$

\begin{tabular}{|c|c|c|c|c|c|c|c|}
\hline No. & Seconds & $\begin{array}{l}\text { Volt. } \\
\text { gas }\end{array}$ & $\begin{array}{l}\text { Cell } \\
\text { gas }\end{array}$ & $\begin{array}{l}\text { Cell oxygen and } \\
\text { chlorine }\end{array}$ & $\begin{array}{c}\text { Cell } \\
\text { hydroger }\end{array}$ & $\begin{array}{c}\text { Percent } \\
\text { reduction }\end{array}$ & $\underset{\mathrm{Cr}}{\mathrm{Mgmm}}$ \\
\hline \multirow[t]{3}{*}{ I } & $\mathrm{IO} 2 \mathrm{O}$ & 96.2 & 62.4 & 23.8 & 39.6 & 38.2 & 14.8 \\
\hline & I 4400 & - & - & - & - & - & - \\
\hline & $\mathrm{IO} 2 \mathrm{O}$ & 95.0 & 95.0 & $3 \mathrm{I} .5$ & 63.5 & - & 0.2 \\
\hline
\end{tabular}

(h) Comparison of Efficiencies.-From the work of Geuther, we may not tell exactly what current densities were used; but 
with an acid of the same concentration (I 4.28 percent) we have by adding impurities been able to obtain results which practically agree with his so far as the rate of metal deposition and hydrogen deficiency are concerned. This is readily seen by comparing 6 and 7 of Table I with $I$ and 2 of Tables VIII and IX. Under no circumstances have we by working within a temperature range of $20^{\circ}$ to $90^{\circ}$, current density of 10 to $25^{\circ}$ amperes, concentration from I percent to 50 percent, been able with a pure acid to get results at all comparable with those of Geuther.

An attempt was made to duplicate Buff's experiment 4, Table III. With the 5.I3 percent solution, he had used electrodes I. 5 square inches in area; the current at its maximum had evolved in the voltameter $\mathrm{I} 4.5 \mathrm{cc}$ of hydrogen per minute. This corresponds to a density of about to amperes per square decimeter if both sides of the cathode are considered. With a voltage of 2.45 and current of 0.025 ampere, we made a run of 4200 seconds; there was no metal deposition and no measurable reduction. The current was now increased to 0.08 ; the corresponding voltage was 2.66. Results are given in Table XIV.

\section{TABLE XIV}

5. I3 percent chromic acid; current $=0.08 \mathrm{amp}$; voltage $=2.66$

$\mathrm{D}$ anode $=\mathrm{D}$ cathode $=20 ; t=20^{\circ}$

\begin{tabular}{c|c|c|c|c|c|c}
\hline No. & Seconds & Volt. gas & Cell gas & $\begin{array}{c}\text { Cell } \\
\text { oxygen }\end{array}$ & $\begin{array}{c}\text { Cell } \\
\text { hydrogen }\end{array}$ & $\begin{array}{c}\text { Percent } \\
\text { reduction }\end{array}$ \\
\hline I & 4020 & 64.5 & 63.2 & 20.1 & 42.3 & 1.6 \\
2 & 3720 & 60.4 & 60.0 & I9.9 & 40.1 & 0.5
\end{tabular}

For this run also, no metal was found. The results correspond with those already given (p. 367) and indicate that at the current density employed the decomposition voltage for metal deposition had not been reached.

It will be seen that the reduction instead of being 95 percent as with Buff is more nearly I $\%$ or $2 \%$. While it must be admitted that the use of the same concentration, temperature and current density does not mean that experimental conditions 
have been accurately reproduced, it would appear that the most reasonable explanation which we can offer for the reduction observed by Buff and Geuther is that the acid they used was impure. Buff's results are not comparable with those of Geuther since the latter was working above the decomposition voltage while the latter was using densities corresponding to points below this.

Our results prove conclusively that Placet and Bonnet were right in stating that metallic chromium can be obtained by the electrolysis of commercial chromic acid. We have also found that otherstatements made by them in their patent, are true.

The failure of so many chemists is probably due to the use of too low current densities, combined possibly with the belief that it could not be done.

The results of Reese were readily reproduced by using a current density which corresponded to a voltage lower than the decomposition voltage; with greater current densities, however, the purest acid is quickly reduced.

Greater efficiency of reduction and metal deposition has been obtained by the addition of sulphuric than with hydrochloric or nitric acid. The pure acid shows very low efficiency of deposition; it is our belief that while a purer acid might show still less, the actual deposition is not always caused by the presence of impurity.

Why does the sulphuric acid increase the efficiency? It is well recognized by electrochemists that the efficiency of a metal deposition varies very considerably with the number of ions of the metal present in the solution. With a small number, low efficiencies are expected; as this number increases, the efficiency will increase. We suggest, therefore, that the sulphuric acid has increased the number of chromium cations in the solution. It is probable that in its presence, the dissociation of the chromic acid is forced back to the $\mathrm{CrO}_{3}$ stage and that the secondary dissociation of this into hexavalent chromium cations is thereby increased.

Another method of expressing the same result is thiswhen sulphuric acid reacts with $\mathrm{CrO}_{3}$, the latter behaves as a 
base, and hexavalent chromium tends to be formed, although normally the trivalent salt is the more stable form. It does not seem at all improbable therefore that the various acids and also various salts tend to increase the ionization of chromium acid to hexavalent ions, and that this effect is shown in the increase of efficiency of deposition of the metal.

(i) Products of Reduction.-In every case examined, where the chromic acid was reduced, the solution was colored brown and the reactions showed the presence of chromic salts. When alkali was also formed at the cathode, there was formed a brown precipitate which on treatment with hydrochloric acid evolved chlorine. This is probably the compound already found by Geuther, Buff and Morges who regard it as $\mathrm{CrO}_{2}$ or chromium chromate, $\mathrm{CrCrO}_{4}$.

A compound corresponding to the same formula has been made by other methods : for example, Maus ${ }^{1}$ found that chromic sulphate or chloride treated with potassium chromate, or chromic hydroxide in the presence of chromic acid reacted to form it. In other words an oxidizing acid or the salt of the acid might be reduced by" a compound in which the element occurred in a lower valency, to a product in which the element had an intermediate valency.

Now these chemical conditions are the ones which have been reproduced in the electrolytic cell. In the solutions to which were added sulphuric, nitric or hydrochloric acid, if a partial reduction could have taken place with formation of the chromic sulphate, nitrate or chloride, there would have been a reaction between these compounds and the chromic acid, with formation of the chromium chromate, heat also being evolved. In other words, the reduction to the $\mathrm{CrO}_{2}$ stage would be more readily effected than the reduction to the trivalent stage.

So also when an alkali salt was added, there might be assumed a tendency for the chromic acid to reduce at the cathode to the chromic salt, which either as chromic hydroxide or the alkaline chromite would, according to the Maus reaction,

\footnotetext{
${ }^{1}$ Pogg. An11, 9, I 27 (1827).
} 
tend to form $\mathrm{CrO}_{2}$. In place of the reaction proceeding in two distinct stages, however, the one observed in the electrolysis was the precipitation of the solid. This was noticed with the solutions used in Tables $\mathrm{X}$ and XIII.

We have already noted that in every case examined, the yield of chromium and the extent of reduction decrease as the reaction proceeds, that is, as the chromic acid changes to its lower stage of oxidation. The conclusion might at once be drawn that the presence of the reaction products decreased the efficiency, were it not that not merely is metallic chromium removed but that the chromium chromate precipitates.

A solution was therefore selected in which this precipitation might to a certain extent be avoided-that used in Table VIII. With $2 \mathrm{cc}$ of this solution corresponding to $48 \mathrm{mgms}$ of the metal, five runs were made under the following conditions: time 960 seconds, current 0.5 amp., $\mathrm{D}$ anode $=\mathrm{D}$ cathode $=125, t=$ $20^{\circ}$. The weights of the deposit were $20, I 8, I 6, I 5$ and 4 mgms respectively, while a slight amount scaled off. The total amount of chromium left in the solution was then about one-half the amount originally present. The sixth run was then made-this is number (6) in Table XV. The original solution was then diluted to one-half and a run made-(I) in Table XV.

\section{TABLE XV}

Chromic + sulphuric $; \mathrm{Cr}$ content $=74$ mgms; current $=0.5$ amp $; \mathrm{D}$ anode $=\mathrm{D}$ cathode $=125 ; t=20^{\circ}$

\begin{tabular}{c|c|c|c|c|c|c|c}
\hline No. & Seconds & Volt. gas & Cell gas & $\begin{array}{c}\text { Cell } \\
\text { oxygen }\end{array}$ & $\begin{array}{c}\text { Cell } \\
\text { hydrogen }\end{array}$ & $\begin{array}{c}\text { Percent } \\
\text { reduction }\end{array}$ & Mgms Cr \\
\hline 6 & 700 & 75.0 & 65.7 & 23.7 & 42.0 & 3.8 & I.O \\
1 & 660 & 70.5 & 40.0 & 2 I.9 & I8.I & 6 I.0 & 15.6
\end{tabular}

While the conditions are not absolutely comparable, the different results obtained in (6) and (I) indicate that the presence of the chromium chromate causes a very decided decrease in the yield.

As stated above, the oxidation power of chromic acid is increased by the presence of an acid-in other words, the chromic 
acid is more readily reduced in the presence of an acid. Is it then possible to reduce the chromic acid quantitatively to a chromic salt by the agency of the current? Le Blanc' says it cannot be done unless a diaphragm is used. "Nur solange man, wie Street, in alkalischer Lösung arbeitet und das Chromoxyd sich unlöslich ausscheidet, wird die Regeneration zu Chromat an der Anode praktisch zu vernachlässigen sein, falls man nicht etwa Diaphragmen zu Hilfe nimmt." Buff found that at low current density chromic acid acidified with sulphuric is readily reduced to chromic sulphate and potassium chromate to chrome alum. To check his statement we took $2 \mathrm{cc}$ of a 14.28 percent chromic acid, $2 \mathrm{cc}$ of concentrated sulphuric acid, and $2 \mathrm{cc}$ of water. No diaphragm was used. With anode density of $75^{\circ}$ amperes, cathode density of 50 amperes, a current of 3 amperes in ten minutes effected complete reduction. Ozone formation was also noted. In fact, this is a very easy method of reducing chromic acid when it is desired to avoid the introduction of organic impurities. The Grove cell offers an illustration of the case where the reduction effect is found when current is being withdrawn from the cell.

A cell which would offer considerable interest is composed of chromium and graphite electrodes in sulphuric and chromic acid. If a diaphragm were used, this would form a storage cell, but its efficiency would probably be very low.

The experiments recorded in Tables IV to XIII have shown therefore some of the conditions by which it is possible to pass from hexavalent chromium to what is probably the tetravalent chromium chromate stage, the metal being deposited while the electrolytic reduction proceeded, but not however until a definite voltage (current density) was reached. The experiment cited in the last paragraph has shown some of the conditions by which the hexavalent may be carried to the trivalent stage. Carveth and Mott examined a few of the conditions involved in the reduction from the chromic to the chromous salts, being concerned more with the efficiencies of metal deposition.

1 "Darstellung des Chroms," p. 72.

${ }^{2}$ Liebig's Ann., ror, 8 (1857). 
Commercial Methods. - It is now easy to see some of the difficulties which are involved in the continuous deposition of chromium from its solutions. If an anode were employed which was practically a pure chromium in an electrolyte of chromic chloride or sulphate, it might seem difficult to select the conditions of concentration, temperature, and current densities at which the rate of solution (apparent anode valency) was exactly counterbalanced by the rate of deposition of the metal. The solution must not become acid because of the ease of decomposition of the chromous salt; in fact a slightly alkaline reaction seems to favor an increased cathode efficiency. It is very probable that the exact conditions for this deposition will be worked out and that as in other cases the sulphate (or chloride) will be the salt employed.

The use of chromic acid or chromates in acid solution will probably be restricted to the cases where fine platings are required, since the current efficiency is very low. Electrodeposition from a fused bath offers very distinct possibilities.

There is no doubt that as soon as the commercial demands warrant, methods for the electrodeposition of chromium in any form will be devised.

(j) Conclusions. - In the study of the cathode reactions, at least three but more probably four or more different stages of oxidation are met; this means that in the various solutions there are chromium ions with four different valencies. When the equilibrium relations between metallic chromium and its ions have been determined, the question will be decided as to whether or not the anode reaction is the converse of the latter.

In regard to the constitution of chromic acid solutions, the following facts must be noted: (A) The study of the equilibrium relations point to the existence of free $\mathrm{CrO}_{3}-$ a radical composed of a conductor and a non-conductor of electricity. So far as we are aware, no known compound of such a combination is known which conducting the current in aqueous solution is not by the supporters of the theory of electrolytic dissociation supposed to be dissociated into ions; (B) Chromium as anode may dissolve to form $\mathrm{CrO}_{3}$. If dissolving to form an ion, this will be hexa- 
valent. There is a continuous passage from the conditions where it dissolves divalent (and every one concedes its ionization because a salt is formed) to the conditions where it dissolves hexavalent (where ionization has not been conceded, because an acid was formed); (C) Chromium may be deposited from chromic acid after a definite decomposition voltage has been reached.

I. This evidence therefore makes it seem very probable that in chromic acid there exists a number of hexavalent chromium cations in equilibrium with many other ions, and that chromium in chromic acid may be considered a reversible electrode.

2. The main part of the work of Geuther is correct. Metallic chromium is deposited in the electrolysis of solutions of chromic acid, but this requires a high current density, which in this case is synonymous with a high decomposition voltage. For example, using platinum wires as electrodes Geuther used currents of from 0.07 to 0.35 ampere-very great densities, probably higher than we have used. On comparing with our own results the very great percentage reductions and the high metal depositions which he obtained we conclude that his acid must have been impure. The oxygen excess which he found at the anode, we have never been able to find; his admission that his tangent galvanometer was wrong probably explains this. After the decomposition point is reached, the efficiency of metal deposition and the reduction of the acid go hand in hand; a chromium chromate is probably formed.

The results of Buff are readily understood when the current density he employed is calculated. Under no conditions have we been able to get deposition of the metal at a current density as low as he used; nor have we with any but very impure acids been able to duplicate his results.

Like Buff, the other workers, Schick, Cowper-Coles and Feree have probably used too low current densities; it seems very improbable that their materials were purer than those used in the investigation.

Some of the claims of Placet and Bonnet are sound. It is very probable that solution of commercial chromic acid and of chromates to which have been added various substances which 
aid in the reduction may not be used in a continuous and economical process for the extraction of chromium, since the efficiency is so rapidly decreased by the formation of the reduction products. By oxidizing these, however, it would be possible to continue the extraction of metal, making the process continuous. There is nothing to prevent the use of this method in the laboratory for the purpose of making pure chromium.

By selection of the proper impurity (e.g., sulphuric acid) we have been able in a continued electrolysis to recover in the metallic form more than half the total chromium present in the solution. Had the reduced products been oxidized, this yield could have been carried to any limits desired.

The criticisms of Le Blanc on the work of Geuther, Placet and Bonnet, and Street need radical change. The only justification for such criticism was due to the experimental conditions not having been described in sufficient detail by the various workers.

3. Electrolytic chromium may occlude as much as two hundred and fifty times its volume of hydrogen.

4. It is possible to reduce chromic acid to the trivalent chromic salts in the presence of an excess of a mineral acid.

As previously stated, we regard chromium merely as the type of a large number of elements which, according to the degree of oxidation, are either acid or basic in their properties. The methods which we have used should, we think, be capable of application to numerous other cases, such as the rare earth elements.

Of the work planned, but a small part is completed. It is our hope that the interest attached to the work will induce other electro-chemists to enter the field.

Comell University, April, 1905. 